\title{
Technè
}

La science au service de l'histoire de l'art et de la préservation des biens culturels

48 | 2019

Les couleurs de l'Antique

\section{The new corpus of painted Imperial Roman marble reliefs from Nicomedia: a preliminary report on polychromy}

Le nouveau corpus de reliefs romains d'époque impériale en marbre peint de Nicomédie : rapport préliminaire sur la polychromie

Mark B. Abbe and Tuna Şare Ağtürk

\section{CpenEdition}

\section{Journals}

Electronic version

URL: https://journals.openedition.org/techne/2567

DOI: $10.4000 /$ techne.2567

ISSN: 2534-5168

\section{Publisher}

C2RMF

\section{Printed version}

Date of publication: 31 December 2019

Number of pages: 100-109

ISBN: 978-2-17-152831-4

ISSN: 1254-7867

\section{Electronic reference}

Mark B. Abbe and Tuna Sare Ağtürk, "The new corpus of painted Imperial Roman marble reliefs from Nicomedia: a preliminary report on polychromy", Technè [Online], 48 | 2019, Online since 01 July 2021, connection on 02 April 2022. URL: http://journals.openedition.org/techne/2567 ; DOI: https://doi.org/ $10.4000 /$ techne.2567

\section{$\circledast \oplus \Theta \Theta$}

La revue Technè. La science au service de l'histoire de l'art et de la préservation des biens culturels est mise à disposition selon les termes de la Licence Creative Commons Attribution - Pas d'Utilisation Commerciale - Pas de Modification 4.0 International. 


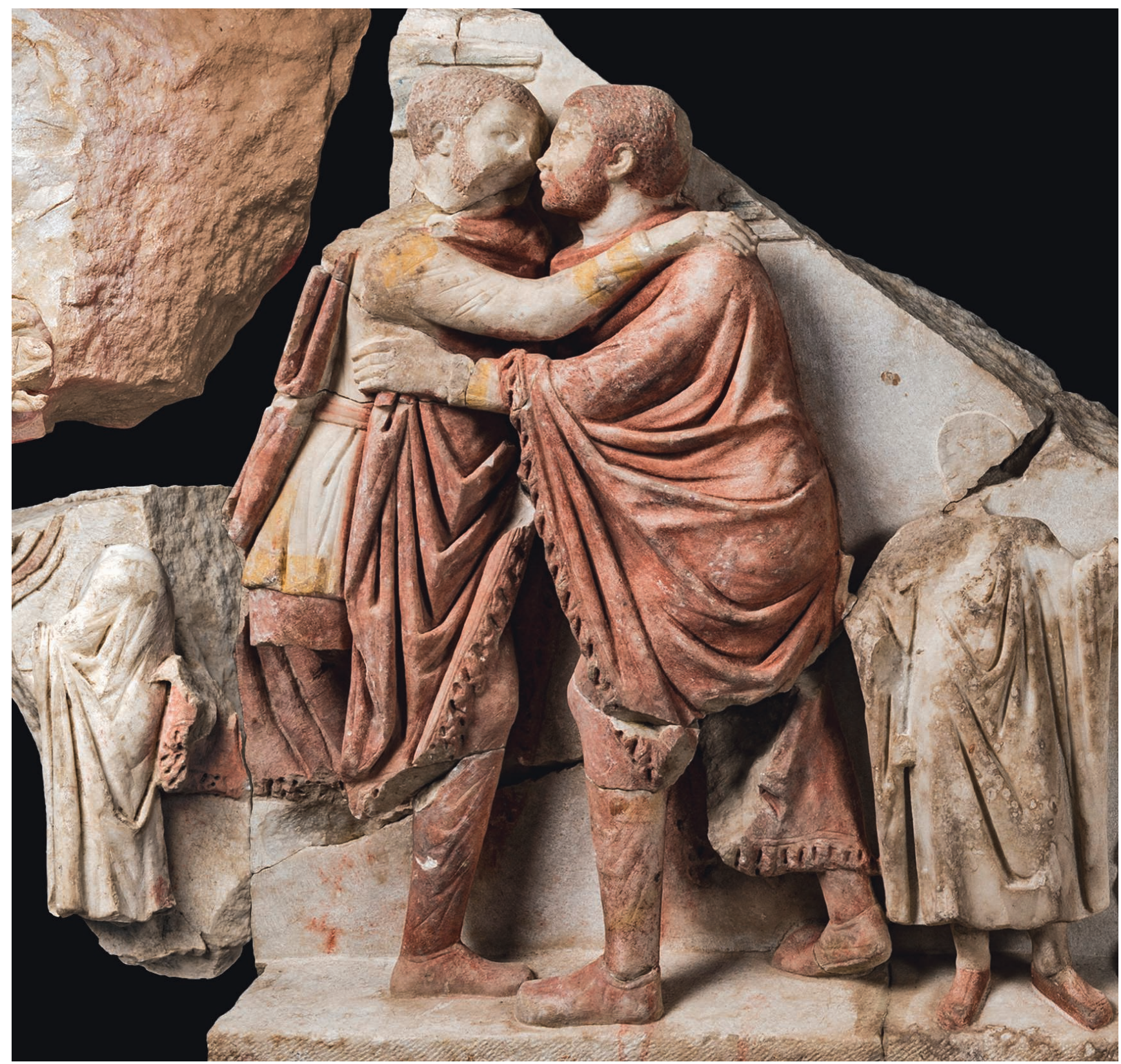

Fig. 1. Relief block with embracing emperors, detail of fig. 7 (H. 104 cm, L. $270 \mathrm{~cm}$ ).

Crediting for all images: Courtesy Çukurbağ Archaeological Project [TÜBİTAK 115K242], Kocaeli Archaeology Museum/multispectral or microscopic details : M. Abbe. 
Mark B. Abbe

Tuna Şare Ağtürk

\section{The new corpus of painted Imperial Roman marble reliefs from Nicomedia: a preliminary report on polychromy}

Le nouveau corpus de reliefs romains d'époque impériale en marbre peint de Nicomédie : rapport préliminaire sur la polychromie

\begin{abstract}
This paper presents an initial report on the extant polychromy on the remarkable series of Roman marble state relief sculptures excavated at a newly discovered Tetrarchic imperial building complex in Nicomedia (Turkey). The reliefs, featuring imperial and other diverse subject matters, retain extensive ancient coloration. A brief discussion of the history of the discovery and excavations surrounding these reliefs and the current Tübitak Archaeological Project is followed with a discussion of their polychromy. Preliminary observations about the painting technique, the range of colors and the palette of pigments and patterning are presented, before focusing on the use of color in the dress of the imperial costumes of the emperors. These exceptional painted state reliefs afford key new insights into the nexus of art, color-coding, sculpture, and court ritual in later Roman culture.

Keywords. Polychromy, Roman, relief, sculpture, Nicomedia, paint, Tetrarchy, Diocletian, Late Antiquity, marble, color.
\end{abstract}

Résumé. L'étude consiste en un premier rapport sur la polychromie du remarquable ensemble de reliefs impériaux sculptés en marbre, mis au jour dans un complexe architectural datant de la Tétrarchie récemment découvert à Nicomédie (actuelle Izmit). Les reliefs, ornés de thèmes impériaux et de divers autres sujets, portent d'importantes traces de coloration antique. Une présentation rapide de l'histoire des fouilles entourant cette découverte et de la campagne archéologique en cours sous l'égide du Tübitak introduit l'examen de la polychromie. Les observations initiales sur la technique picturale, la gamme de couleurs, la palette de pigments et le répertoire de motifs sont complétés par une étude plus fouillée des couleurs employées pour les costumes des empereurs. Ces exceptionnels reliefs peints de caractère public apportent des informations décisives sur les liens entre art, code de couleurs, sculpture et rituels de cour dans la culture romaine tardive.

Mots-clés. Polychromie, romain, relief, sculpture, Nicomédie, peinture, Tétrarchie, dioclétien, Antiquité tardive, marbre, couleur.

\section{Introduction}

Ancient Nicomedia, once the capital of the eastern Roman Empire with its magnificent urban landscape, now lies just below the industrial city of İzmit in Turkey. This article offers the preliminary results of the initial polychromy research on a series of painted marble reliefs from a monumental Imperial complex recently discovered in Çukurbağ district, at the heart of modern İzmit ${ }^{1}$. The complex dates from late 3rd century and its reliefs form a frieze with an astonishing combination of imperial and mythological depictions ${ }^{2}$. The importance of this discovery is hard to overstate. The later Roman Empire in the east, more specifically, emperor Diocletian's imperial seat in Nicomedia, has now a defining monument. The depictions on the Nicomedia frieze shed light on the socio-political circumstances and their reflection in later Roman state art. Furthermore, the reliefs, as the only surviving examples of
Roman relief sculpture with extensively preserved paint, elucidate aspects of ancient sculptural polychromy in this period of increased color-coding and color-symbolism in imperial iconography. Below, a brief historical overview of ancient Nicomedia and the recent archaeological investigation in Cukurbağ will be followed by a discussion of our initial investigation of the polychromy of the frieze based on multispectral imaging, microscopy, and in situ p-XRF (portable X-ray fluorescence spectroscopy).

\section{Nicomedia - A Historical Overview}

Strategically located between west and east, Nicomedia, along with its protected harbor in the Propontis, was a major naval, industrial, and trade center throughout Antiquity despite numerous devastating earthquakes. According to Strabo

Mark B. Abbe, Associate Professor of Ancient Art, University of Georgia, Athens, Georgia, United States (abbe@uga.edu). Tuna Şare Ağtürk, Associate Professor of Art History and Archaeology, Canakkale Onsekiz Mart University, Canakkale, Turkey (tunasare@comu.edu. tr). European Commission Marie Curie Fellow at Oxford University, Faculty of Classics (2019-2021) (tuna.sareagturk@classics.ox.ac.uk). 


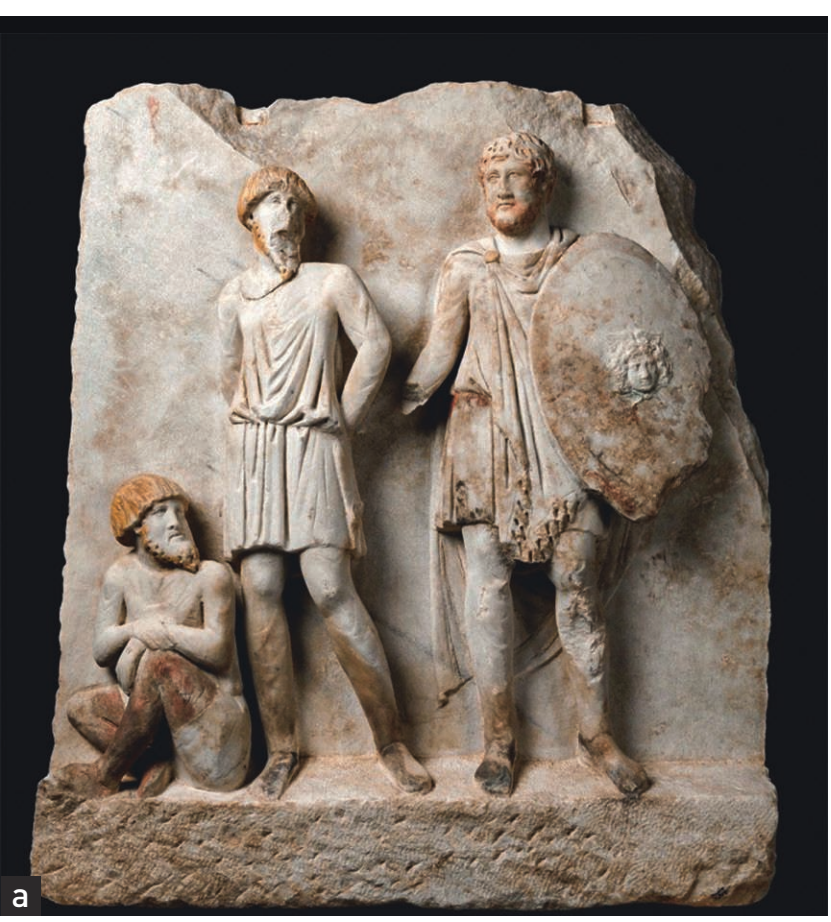

102
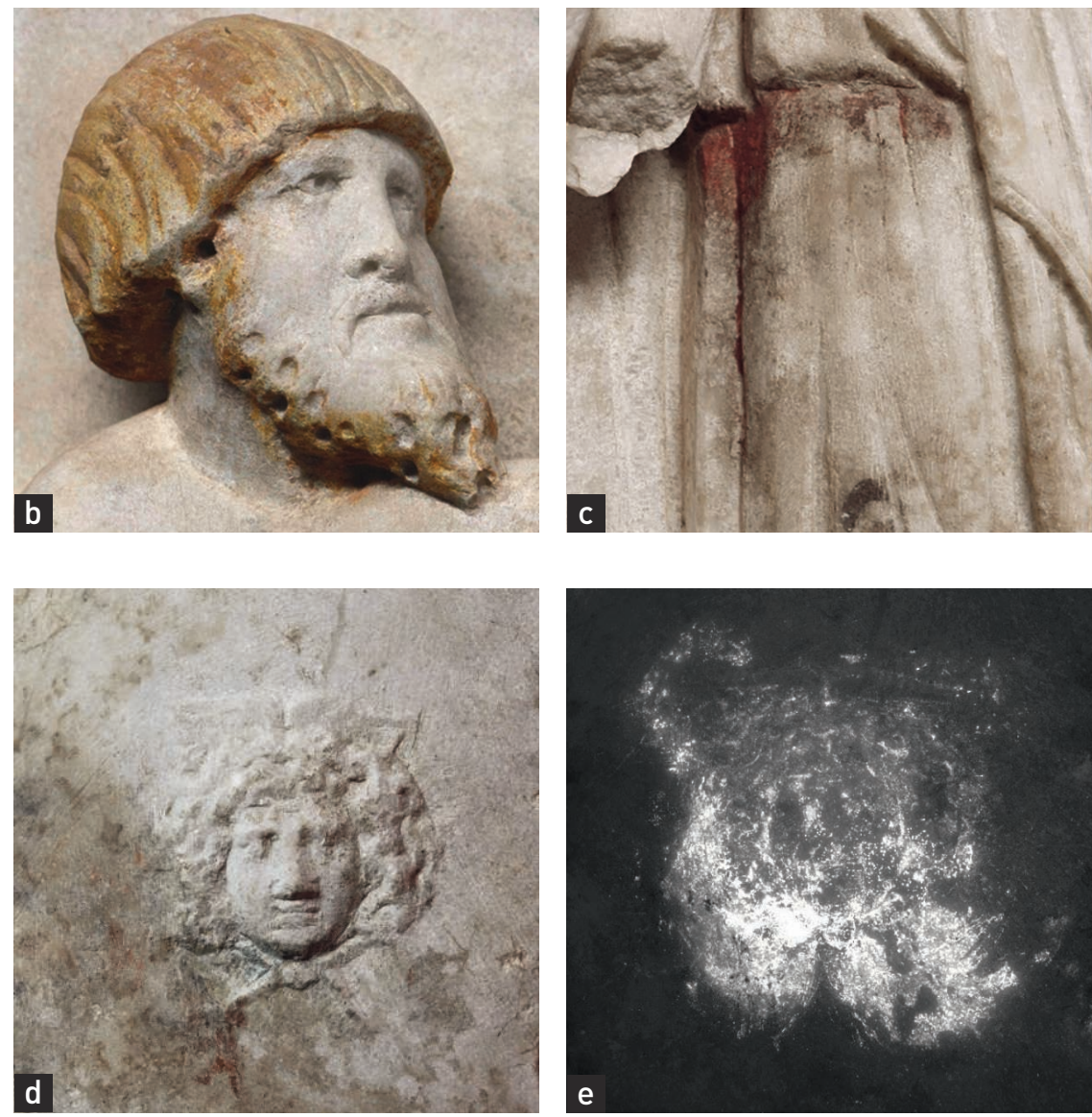

Fig. 2 a-e. Relief block with Roman soldier with bound barbarian captives: a. Overall (H. $105 \mathrm{~cm}$, L. $93 \mathrm{~cm})$; b. Detail of barbarian with yellow hair color; c. Detail of legionary's tunic; d. Detail of shield gorgoneion; e. Detail of shield gorgoneion in VIL.
(Geographica 12.4.2), the city was founded in 264 B.C. by Nicomedes I and became the leading city of the Hellenistic kingdom of Bithynia. In 74 B.C., it was designated the capital of the Roman province of Bithynia, and, after the ascent of Diocletian to the imperial throne in 284 A.D., it became the capital of the eastern Roman empire. The city seems to have reached its peak from then until the transfer of the imperial capital to Constantinople in 330 A.D. The catastrophic earthquakes of 358 and 386 A.D. severely damaged the city and subsequent earthquakes, in the Medieval period, diminished its significance, but it maintained its role as a major regional urban center up till today. The large size and impressive structures of ancient Nicomedia, especially during the late 3rd and early 4th centuries, were described in many Roman literary sources. Lactantius, a resident of the city during Diocletian's rule, refers to Diocletian's exhaustive building activity as part of his attempt to transform Nicomedia into "a rival of Rome" (De mortibus persecutorum 7.8, 10). Also, Libanius in his lament to Nicomedia after the mid 4th century earthquakes offers a detailed account of how Nicomedia's magnificent urban structures perished in the earthquakes (Oration 61.15-17). Because the ancient city lies directly underneath the modern town, Nicomedia has never been systematically excavated. Thus, the imperial complex and the painted frieze it once adorned form the most concrete archaeological data found about this celebrated ancient city ${ }^{3}$.

\section{The Çukurbağ Excavations (2001,} 2009) and the Tübitak

Archaeological Project (2015-2018)

The first reliefs and architectural elements from Çukurbağ were recovered during rescue excavations conducted by the Kocaeli Museum in 20014 . Excavators salvaged parts of approximately 11 relief panels with notable amounts of color. In 2009, two months of expansive rescue excavations revealed a large area, measuring approximately $400 \mathrm{~m}^{2}$, about 22 metres above the sea level, of a large building complex and a large corpus of reliefs with painting. The reliefs, many of which retained significant remains of color, were transferred to the Kocaeli Museum, while architectural finds were stacked on top of one another and left on site. Due to ongoing legal investigations into the smuggling of some reliefs during the 2009 salvage expedition, the relief sculptures were kept in boxes and were never properly studied until the start of Çukurbağ Archaeological Project. 

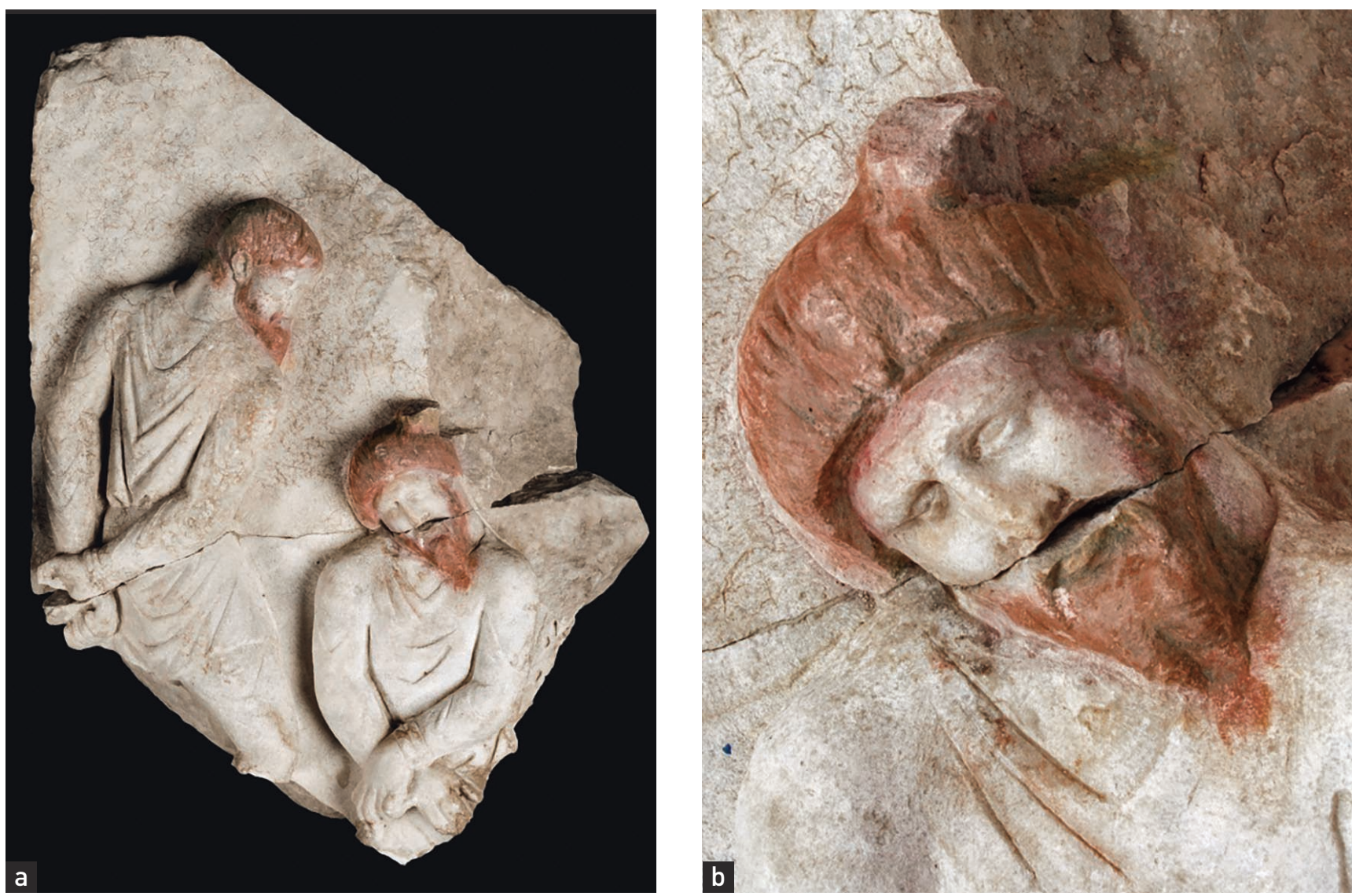

Fig. 3 a-b. Relief block fragment with bound barbarian captives: a. Overall (H. $86 \mathrm{~cm}$, L. $64 \mathrm{~cm})$; b. Detail of barbarian with reddish orange hair color.

The new archaeological project started in 2013 and was funded in 2015 by TÜBİTAK. The main purpose of this project is to analyze the sculptural and architectural finds as a whole and to identify the complex to which they once belonged. As of now, the catalogued Çukurbağ finds include 66 large fragments of architectural relief panels, all made of medium to coarsegrained white marble with grey-blue banding, presumably from Proconnesos (fig. 1 to 7 ). At least 20 of these slabs are fully preserved, with an average height of 1.0 metre; other finds include 129 smaller fragments of relief panels, 62 fragments of freestanding statues (from colossal to smaller than life-sized), and dozens of architectural elements, including an opus sectile floor, columns, capitals, and cornice and architrave blocks. The sumptuous variety of marble is also worth noting. Based on archaeological study and macroscopic geological examination, this includes: three sizes of Corinthian capitals of Proconnesian marble, two sizes of Aeolian granite columns, cipollino columns from Euboea that are close in size to the smaller granite columns, small pavonazzetto columns from Docimium that perhaps originally supported small-scale Proconnesian pediments of the aedicules, and large cornice and architrave blocks of Proconnesian marble. The variety of marbles is also reflected in the opus sectile floor. A new excavation of the southern part of the building initiated in 2016 revealed monumental stairs leading to the complex which the sculpture and the architectural elements had belonged. The initial examination of the architectural elements indicates that the continuous frieze mostly decorated the entablature of an aediculated hall with at least two stories. The reliefs depict Roman military expeditions, imperial rulers and soldiers in battle with barbarians, processions and religious ceremonies, as well as mythological narratives, agonistic games, and theatrical performances. The combination of such themes in one monumental structure with an opus sectile floor suggests that what we have is a hall of imperial cult, part of a much larger imperial complex, which might have initially functioned to glorify the triumph of Diocletianic rule in Nicomedia ${ }^{5}$. The archaeological evidence shows that the complex came down all at once while still in use, perhaps with the major earthquake in 358. The well-preservation of the color on the late 3rd century frieze may in significant part be due to its short life of exposure in the hall.

\section{Polychromy}

The painting preserved on the marble reliefs from Nicomedia is unprecedented in the large corpus of Roman state relief sculpture. No other state monument preserves such extensive applied polychromy, including those from Rome itself, and other reported remains of color are vestigial ${ }^{6}$. The ancient 

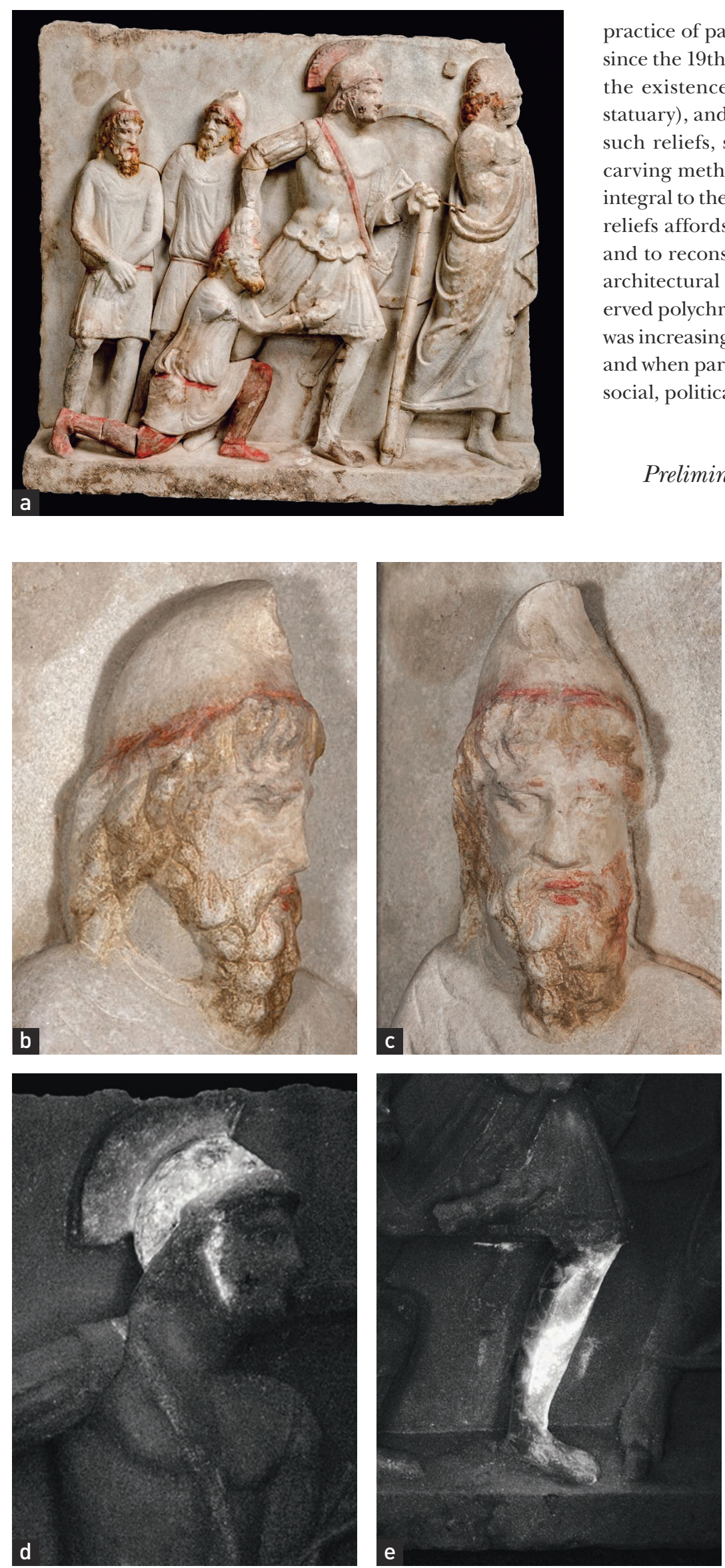

practice of painting marble state relief has not been in doubt since the 19th century (unlike the extensive debates regarding the existence and extent of color on freestanding marble statuary), and the pictorial effects employed in the carving of such reliefs, such as drilled outline techniques, chiaroscuro carving methods, and "coloring by shadows" have long been integral to their study ${ }^{7}$. The exceptional color of the Nicomedia reliefs affords an opportunity to examine state relief in color and to reconstruct this coloration in context within a defined architectural environment. It is most fortuitous that this preserved polychromy heralds from a historical period when color was increasingly emphasized in imperial costume and imagery, and when particular colors, including purple, had heightened social, political and material associations.

\section{Preliminary observations}

Despite variations in size, format and style, the sculpted friezes from Nicomedia are consistent in their ancient marble technique: they uniformly make no use of bronze attachments and avoid marble piecing, suggesting that the reliefs were considered to be structurally and materially integral to their larger architectural frame.

It is notable that there is no evidence for the application of color to the background of the sculpted reliefs, although background colors, particularly blue, have often been postulated (based on limited evidence) for many Roman state monuments ${ }^{8}$. The absence of background color on Nicomedia reliefs highlights how the use of color and variations of color were central to the definition, legibility, and reception of the reliefs, as well as the visual hierarchy of the reliefs' diverse subjects and themes. The approach at Nicomedia is notably different from the extensive use of contrasting background colors (including blue) to differentiate subjects and hierarchy in the contemporaneous Tetrarchic imperial wall paintings at Luxor Temple in Egypt ${ }^{9}$.

Fig. 4 a-e. Relief block with Roman cuirassed soldier with bound barbarian captives: a. Overall (H. $98 \mathrm{~cm}$, L. $105 \mathrm{~cm})$; b. Detail of head of barbarian with yellow hair color; c. Detail of face of barbarian; d. Detail of helmet in VIL; e. Detail of greave in VIL. 
The extant painting on the relatively short-lived reliefs appears to be from a single phase of polychrome decoration and displays a largely uniform painting technique. Most of the paint surfaces are heavily abraded from burial and excavation such that only remains of one paint layer is observed. This generally appears as a thick, opaque paint application, akin to the foundational underpainting preserved on freestanding marble statuary (fig. 3 b). Evidence for the building up of color is preserved on a promising number of reliefs (e.g. fig. $6 \mathrm{a}, 7$ ), preferentially in sculpted recesses (fig. $6 \mathrm{c}$ ) and in areas adjacent to the relief background where shadows were often rendered (fig. $4 \mathrm{c}$ ).

The painting appears to have been applied directly on the marble surface and is large-scale, characterized by the efficient use of large brushes to cover significant areas of color. Extensive legible brush strokes remain in the painting, which often extends adjacent to and beyond the drilled outlines of the sculpted relief. The painting technique is consistent with reliefs that were not intended to be viewed intimately. Paint drip lines indicate that the painting was applied when the reliefs were vertically oriented, undoubtedly after they were securely positioned within their architectural surround. Such drip lines are especially prominent on reliefs with imperial subjects where the thickly applied and distinctive deep reddish paint of their purple garments (chlamydes and paludamenta) ran in drip lines over the front edge of the relief blocks, such as on the recently published adventus panel depicting the meeting of the diarchs Diocletian and Maximian $^{10}$ (fig. 7, center bottom).

The architectural re-contextualization of these sculpted reliefs should afford a nuanced understanding of their ancient viewing and the opportunity to model distances, elevations, and lighting conditions as well as the narrative sequencing of the reliefs. In this regard, it is notable that no remains of gilding have been found in the polychromy of the relief friezes, though architectural elements (including acanthus pilasters and decorative reliefs) and free-standing sculptures found in immediate proximity to the reliefs retain significant evidence for leaf gilding.

\section{Extant color patterns}

The extant color is dominated by iron-based reds, oranges, and browns, with more limited use of brilliant mercury-based reds (presumably cinnabar) and lead-based orange-reds. Carbon black, different shades of copper-based Egyptian blue mixed with calcium whites, and isolated remains of organic pink colorants are less readily visible. It is expected that more detailed investigations and analyses of forty samples, currently underway, will demonstrate that the painting techniques and practices are far more nuanced than these preliminary observations suggest. For example, on the imperial garments, the distinctive purple was created by overlapping cinnabar red with a mixture of a now vestigial organic pink lake and Egyptian blue (fig. $6 \mathrm{~d}$ ). In situ $\mathrm{p}-\mathrm{XRF}$ indicates that a brilliant mercury-rich red cinnabar is used selectively for red lips, mouths, shoes, and other ornamental elements with most foundational colors being executed in iron-rich yellows, reds, and browns.

Color is preserved most abundantly on the battle and imperial scenes. The barbarians of different ethnicities display distinct hair colors and styles including blond cropped hair and beards (fig. $2 \mathrm{a}-\mathrm{b}$ ), straight reddish-orange hair and pointed beards (fig. 3 a-b) and long shaggy blond hair and beards paired with conical caps (fig. $4 \mathrm{a}-\mathrm{c}$ ). All of these hair colors are rendered in a variety of iron-rich pigments, and are paired with colorful ethnic dress, such as the brilliant cinnabar leggings and cap of the prominent barbarian in submissio (fig. 4 a). The standing captive barbarian at the far left of the relief retains paint that illustrates the painting process. The head, $10 \mathrm{~cm}$ in height (18 with cap), of this stock figure was painted to be seen from a distance (fig. 4 b-c) including the mercury-rich highlights of the mouth. The beard and hair are rendered in an iron-rich yellow. On the inner sides of the head near the background plane of the relief, a second layer of darker reddish on these areas create a painterly shadow. Key facial features, including the eyebrows, bags under the eyes, pupils and nostrils are rendered with quick brushstrokes a quarter of a centimetre wide in this same color, while the lips and border of the cap are picked out in brilliant red cinnabar. This figure, which has a thick Egyptian blue on its leggings, is of course one of the background cast: the viewer's attention and visual focus are on the central kneeling barbarian elite (with bright red cinnabar leggings and cap) in the foreground.

While barbarian costume varies, more attention in sculpted definition and painting is given to the Roman military and imperial figures and their costumes. Egyptian blue mixed with calcium-based white is abundant on metal swords, spear tips, helmets and greaves, quivers, and shield bosses, as evident in both examination and VIL imaging (fig. 4 a, d-e, fig. $5 \mathrm{a}-\mathrm{c}$ ). Some shields have diamond shield bosses and laurel leaf wreaths (discernible in UV light) within a red cinnabar border (fig. 5 a, d-f). Other more elaborate shields have red borders and black border elements framing sculpted and painted gorgoneia (fig. 2 a, d-e). These Roman figures' costumes receive greater definition with fringed chlamydes, cinnabar belts and vestiges of painted black oval design along their tunics (fig. 2 a, c).

\section{Imperial costume}

The most elaborate and colorful costumes on the reliefs, however, are reserved for emperors. A relief depicting an emperor, undoubtedly Maximian crowned by Herakles, wears cinnabarpainted leggings and bordered garments (fig. 6 a). His travelling chlamys displays a complex pigment mixture to obtain a specific reddish-purple color that appears reserved solely for this and other imperial cloaks on the reliefs. This painting remains thickly preserved on this relief in areas in the drill channels (fig. 6 b-c). It features two paint layers: first the thick, opaque mixture of iron-based red, cinnabar and lead, on top 


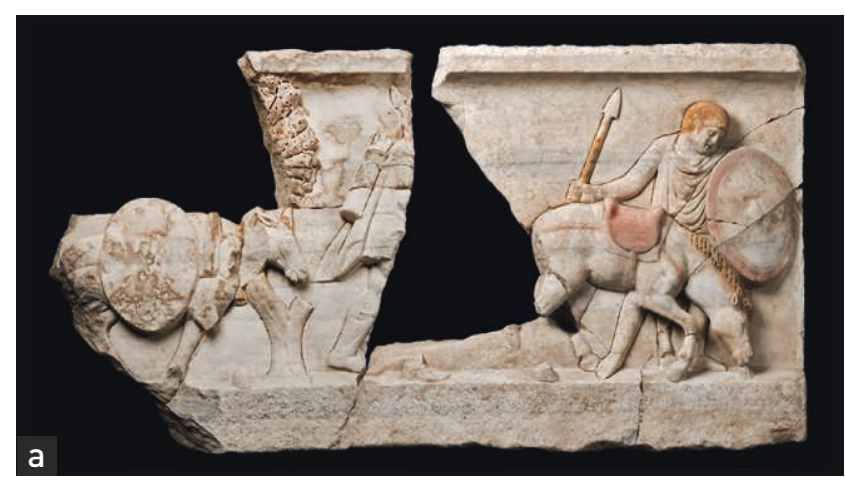

Fig. 5 a. Relief block with figures and horses in outdoor landscape: a. Overall (H. $106 \mathrm{~cm}$, L. $262 \mathrm{~cm}$ )
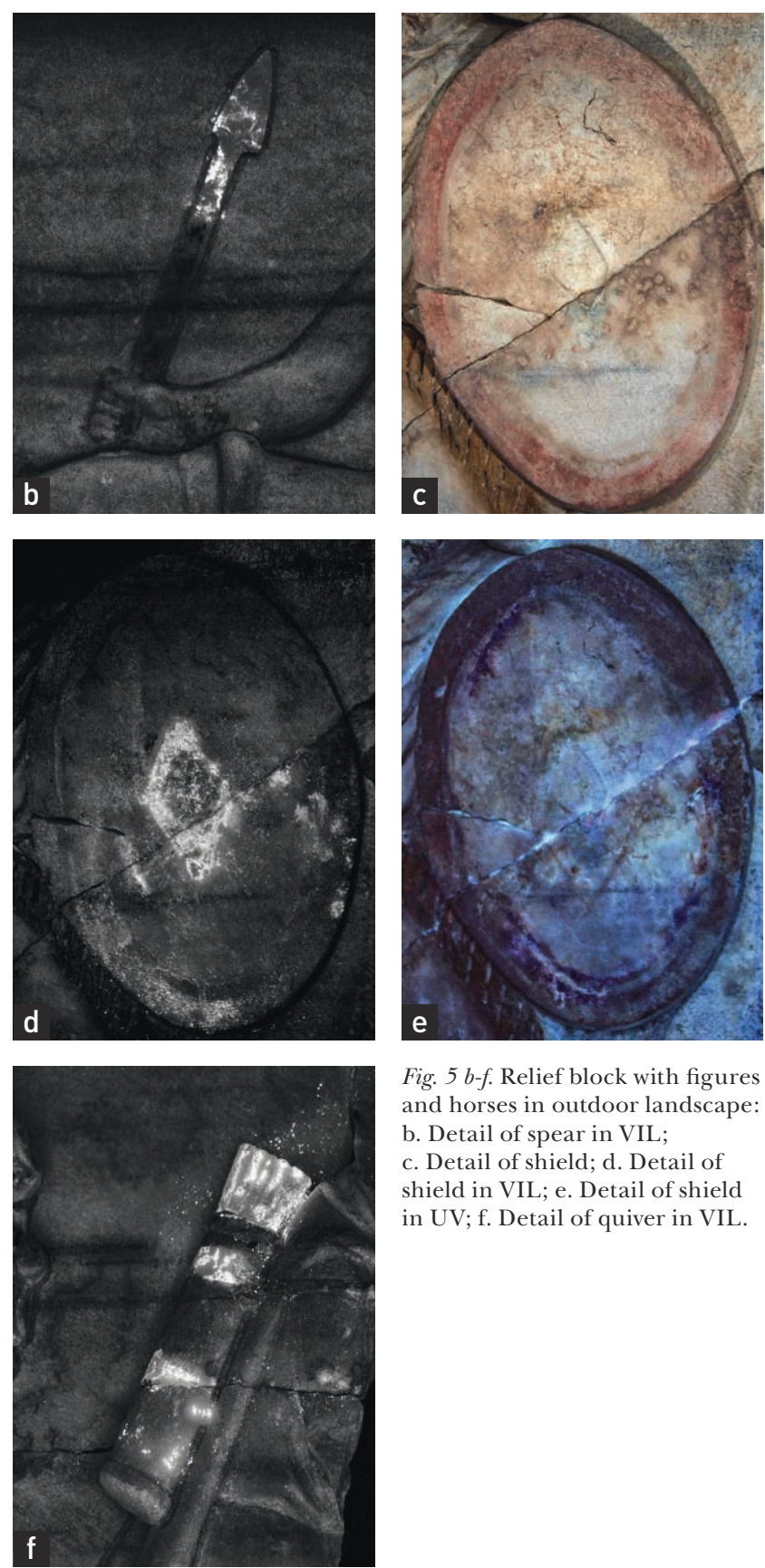

of which remains fragmentary vestiges of a second overlaid paint layer of an organic pink precipitated on a calcium-white, visible in microscopy combined with particles of Egyptian blue (fig. 6 b, d). Such layering of red and pink mixed with blue was a standard method of achieving purple in Roman painting, and here this complex combination of pigments and paint layering obtained the desired imperial purple color. Only imperial subjects display this combination of pigments on their imperial clamydes and paludamenta, indicating this purple color was an imperial domain on the reliefs. Such color-coded costume aided the immediate legibility and differentiation of the imperial subjects on the sometimes-densely packed figural frieze.

Some of the best-preserved painting is on a prominent narrative focus of the reliefs - the astonishing adventus scene of emperors embracing, representing the culminating moment of an imperial procession (fig. 1, 7, 8 a). Nikai, their sculpted blue-painted wings still preserved on the background relief, flank the central embracing emperors, both of whom appear to have been similarly awash in purple, composed in the manner previously described. Having both descended from their flanking purple chariots, for all of their similitudo, they are clearly and emphatically differentiated, not only in their standing height and the height of their flying Nikai, but also, conspicuously, in their hair color (fig. 8 a): the taller, elder greeting emperor at left (Diocletian) has a light gray brown color, while the emperor at right (Maximian) has a remarkably different red hue. In preliminary p-XRF, the hair on both portrait heads displays traces of iron, lead, and copper, but with significantly more iron in the hair at left and more lead at right. VIL imaging suggests how different these paint layers are in the very different use of Egyptian blue (fig. 8 b). While no Egyptian blue appears to be preserved from flesh tones in general, microscopic examination paired with examination in ultraviolet light may suggest the partial preservation of flesh tones in these areas (fig. $8 \mathrm{c}$ ). This relief with its remaining polychromy has much to add to our understanding of the much-discussed similitudo, fraternitas, and aequalitas of Tetrarchic imagery ${ }^{11}$.

This remarkable adventus relief, adorning a frieze of this new imperial chamber at Nicomedia, itself representing an imperial procession, illustrates the intimate nexus where polychrome sculpture, color-coding, panegyrical topoi, and court ritual uniquely coalesced in later Roman imperial culture. We are exceptionally fortunate that the new corpus providing our best-preserved painting of Roman state relief sculpture should be preserved in such a rich and key historical context: Nicomedia, the sedes imperii of eastern Roman empire in the 280s and 290s. 

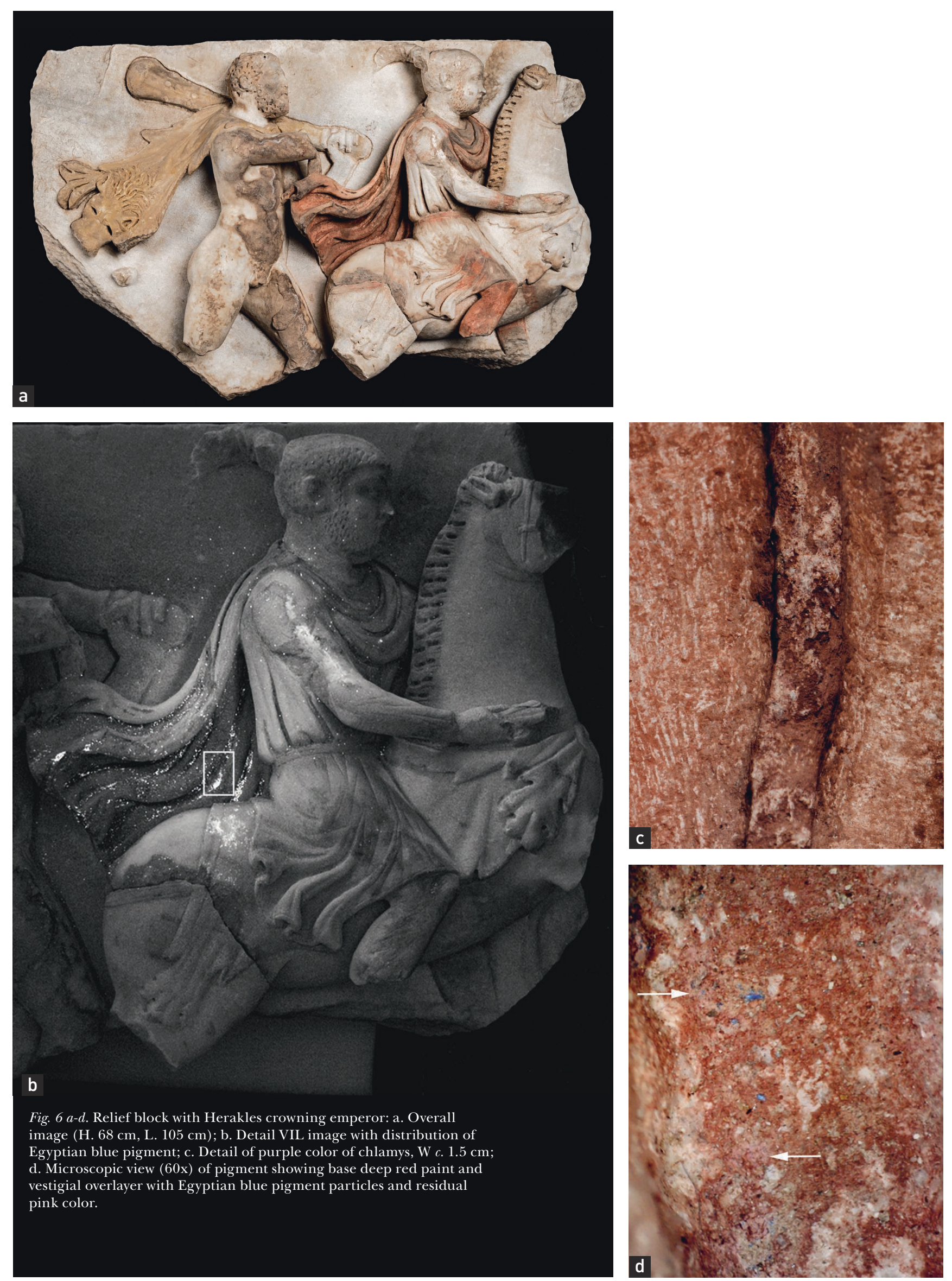


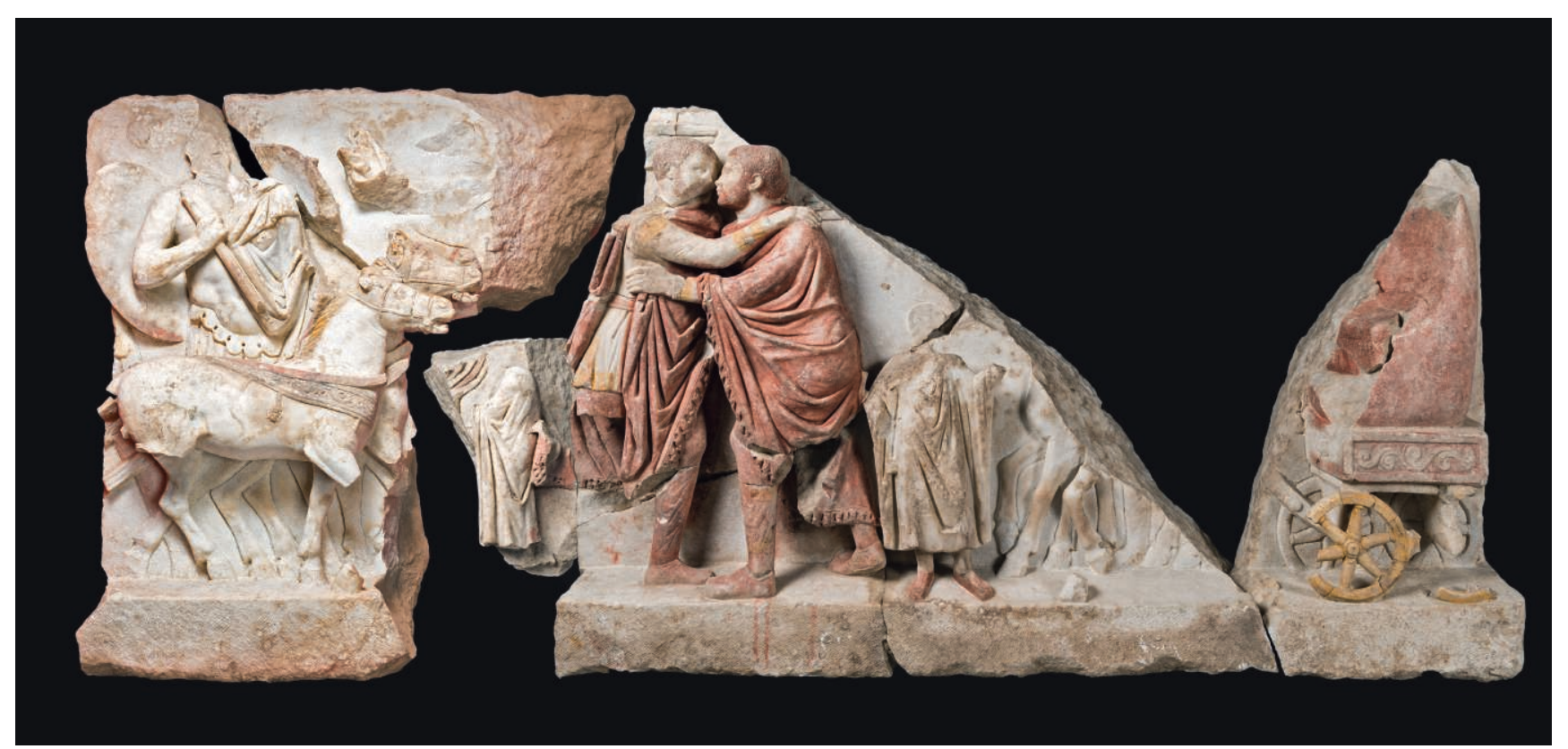

Fig. 7. Relief block with embracing emperors (H. 104 cm, L. 270 cm)

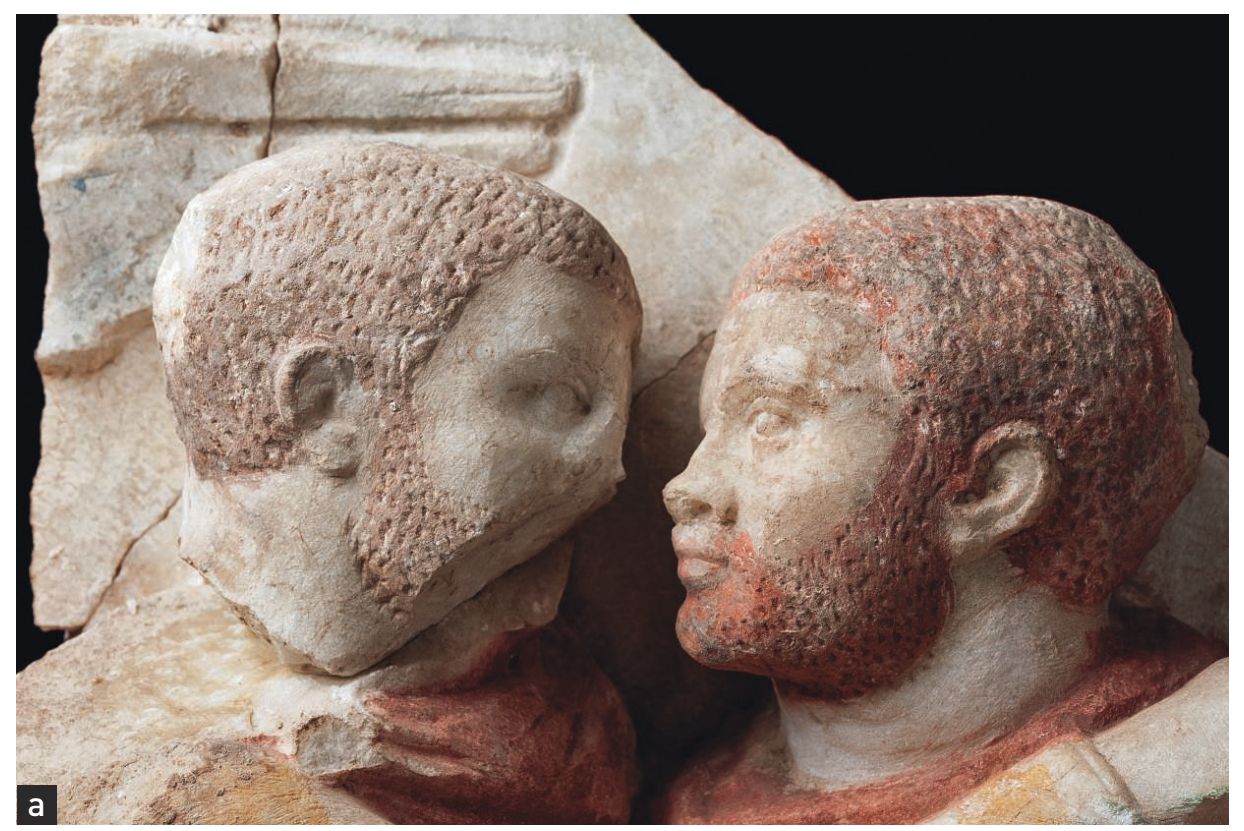

Fig. 8 a-c. Detail of portrait heads of relief block with embracing emperors:

a. In ambient light;

b. In VIL; c. In UV light.
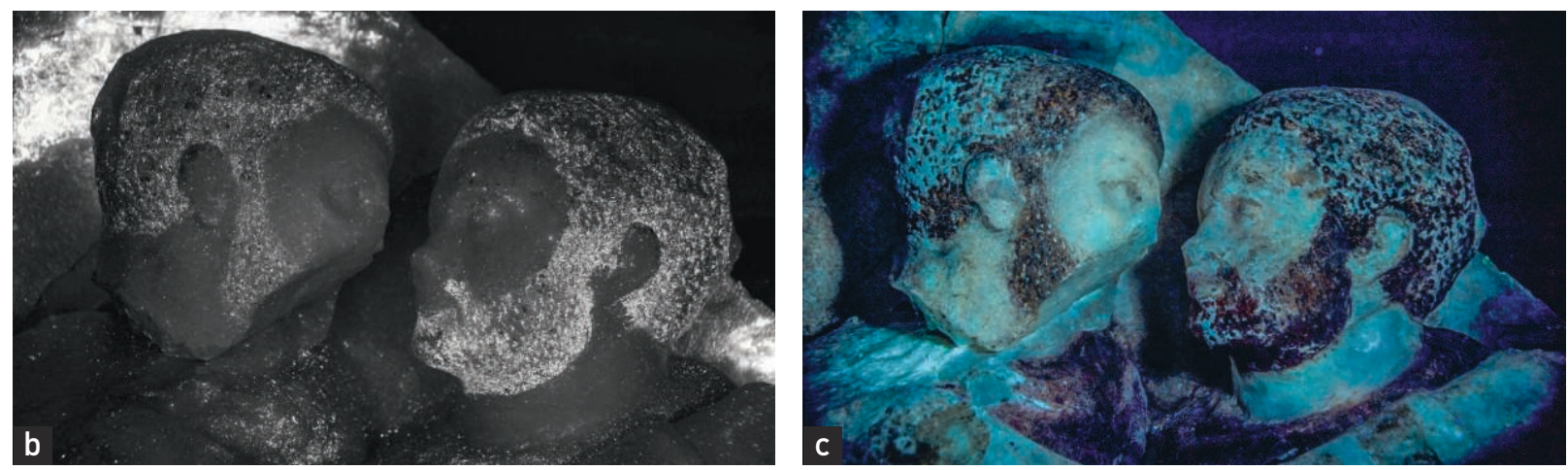


\section{Experimental Appendix}

\section{USB microscopy}

An AM7915MZTL (10-140x) Edge Series Dino-Lite USB Microscope was used for examination. In situ image measurements are approximate.

\section{VIL and UV imaging}

VIL images were obtained using a XNite modified Nikon D330s (the built in ultraviolet and infrared filter removed and replaced by a quartz filter). The radiation source was an Excled Par64 LED Beamer with LB300R, 50W with emission centered at $629 \mathrm{~nm}$. The camera was fitted with one of two filters depending on the amount of luminescence and ambient conditions: B+W 72 IR filter $(830 \mathrm{~nm})$ and LDP LCC X-Nite 1000B filter $(1000 \mathrm{~nm})$. UV images were obtained using an unaltered Nikon D810 camera with radiation from a XNite BFLUV/HID, 35/50 W light source.

\section{$p-X R F$}

In situ analysis was conducted by Dr. Abdullah Zarasiz, of Ankara Nuclear Research Center, using a portable INNOVX, Alfa model spectrometer with a silver (Ag) anode tube with settings at maximum $35 \mathrm{kV}$ and $5.0 \mu \mathrm{A}$ and acquisition times of 60 seconds or longer, depending on the geometry of the sample areas. The p-XRF spectrometer irradiates areas with a circular exposure spot size of $c .0 .75 \mathrm{~cm}^{2}$.

\section{Notes}

1. This article stems from the Cukurbağ Archaeological Project, a large ongoing project conducted with the permission of the Kocaeli Archaeological Museum and the Turkish Ministry of Culture and supported by The Scientific and Technological Research Council of Turkey (TÜBİTAK) (Project 115K242). The authors would like to thank Kocaeli Museum officials, especially director Rıdvan Gölcük and TÜBITAK for making this research and access possible. Additional polychromy research funding has come from the Franklin College of Arts and Sciences, University of Georgia.

2. Previous publications include Sare Ağtürk, 2015, 2017 and 2018.

3. For early scholarship and earlier archaeological investigations, see Şare Ağtürk, 2018, p. 414-415.

4. The result of this initial excavation is published by in Zeyrek, Özbay, 2006.

5 . For the thematic program of the frieze, see Şare Ağtürk (forthcoming).

6. Examples: Del Monte, Ausset, Lefevre, 1998; Rossini, 2009; Fine, Schertz, Heinrich, Sanders (forthcoming).

7. See F. Wickhoff's pioneering and searching description of the Arch of Titus in such terms: 1910, 76-ff.

8. On background color, most recently, informed: Liverani, 2018, p. 379-385; speculative: Pogorzelski, 2015.

9. The Luxor Temple wall paintings, especially the apse with the figures of the
Tetrarchs, is a key overlooked reference point. Now wonderfully documented in Jones, McFadden, 2015.

10. Recent detailed discussion, see Şare Ağtürk, 2018.

11. Hekster, 2015, p. 277-287.

\section{Bibliography}

Del Monte M., Ausset P., Lefevre R. A., 1998, "Traces of Ancient Colours on Trajan's Column", Archaeometry 40, p. 403-412.

Fine S., Schertz P., Heinrich P., Sanders D. (forthcoming), "The Arch of Titus in Color: Polychromy and the Spoils of Jerusalem Panel”, in S. Fine (ed.), The Arch of Titus: From Rome to Jerusalem and Back, Penn State University Press, University Park.

Hekster O., 2015, Emperors and Ancestors. Roman Rulers and the Constraints of Tradition, Oxford University Press, Oxford.

Jones M., McFadden S. (eds.), 2015, Art of Empire. The Roman Frescoes and Imperial Cult Chamber in Luxor Temple, Yale University Press, New Haven.

Liverani P., 2018, "Reflections on Colour Coding in Roman Art", in P. Jockey (ed.), Les arts de la couleur en Grèce ancienne... et ailleurs : approches interdisciplinaires, École française d'Athènes, Athens, p. 367-385.

Pogorzelski R., 2015, Der Triumph: Siegesfeiern im antiken Rom: ihre Dokumentation auf Ehrenbögen in Farbe, Nünnerich-Asmus Verlag, Mainz.
Rossini O., 2009, "Ara Pacis. I colori del binaco", Archeo 25.1, p. 66-75.

Şare Ağtürk T., 2015, "Painted Reliefs from Nicomedia: Life of a Roman Capital City in Colour", Antiquity Project Gallery 89 (346), http://archive.antiquity.ac. uk/projgall/sare 346.

Şare Ağtürk T., 2017, “İmparatorluk Başkenti Nicomedia'nın Ren- kli İhtişamı: Çukurbağ Kurtarma Kazılarında Ortaya Cikarılan Görkemli Roma Anıtı”, in H. Selvi, B. Çelik, İ. Şirin, A. Yeşildal (eds.), Uluslararası Gazi Süleyman Paşa ve Kocaeli Tarihi Sempozyumu Bildirileri/Proceedings of the III. International Symposium on Gazi Süleyman Paşa and History of Kocaeli, p. 343-358, Kocaeli Belediyesi, Kocaeli.

Şare Ağtürk T., 2018, "A New Tetrarchic Relief from Nicomedia: Embracing Emperors", American Journal of Archaeology 122.3, p. 411-426.

Şare Ağtürk T. (forthcoming), "The SelfImage of a 'New' Imperial Capital City on the Tetrarchic Reliefs of

Nicomedia”, in A. Lichtenberger, T. Şare Ağtürk, K. Zimmerman (eds.), Nikaia und Nikomedeia, Asia Minor Studien, vol. 93.

Wickhoff F., 1910, Roman Art. Some of Its Principles and Their Application to Early Christian Painting (trans. A. Strong), W. Heinemann, London.

Zeyrek T. H., Özbay I., 2006, "Statuen und Reliefs aus Nikomedeia”, IstMitt 56, p. 273-316. 